\title{
Histamine release after injection of benzodiazepines and of etomidate. A problem associated with the solvent propylene glycol
}

\section{Libération d'histamine après injection de benzodiazépines et d'étomidate. Rôle du solvant propylène-glycol}

\author{
A. DOENICKE *, W. LORENZ ${ }^{*}$, R. HOERNECKE *, A.E. NEBAUER *, M. MAYER * \\ * Institut für Anaesthesiologie der LMU München, Innenstadtkliniken, Pettenkoferstraße 8a, 8000 München 2, Germany \\ ** Theoretische Chirurgie, Philipps-Universität, Marburg, Germany
}

\begin{abstract}
RÉSUMÉ : Beaucoup de médicaments, surtout quand ils sont injectés rapidement, peuvent induire une libération d'histamine. Une étude en " cross-over » et simple aveugle a été réalisée chez dix volontaires sains. Ils ont été prémédiqués avec respectivement $10 \mathrm{mg} \cdot 70 \mathrm{~kg}^{-1}$ de diazépam i.v. et $1 \mathrm{mg} \cdot 70 \mathrm{~kg}^{-1}$ de lormétazépann i.v., $30 \mathrm{~min}$ avant une injection intraveineuse de $0,15 \mathrm{mg} \cdot \mathrm{kg}^{-1}$ d'étomidate. Le lormétazépam et l'étomidate ont produit des augmentations distinctes du niveau d'histamine plasmatique chez deux sujets. Les pics maximaux d'histamine après lormétazépam ont été respectivement de 2,05 et $2,7 \mathrm{ng} \cdot \mathrm{ml}^{-1}$ et, après étomidate, de 1,85 et $3,2 \mathrm{ng} \cdot \mathrm{ml}^{-1}$. Les deux médicaments sont solubilisés dans le propylène-glycol, solvant qui confère une très haute osmolalité $\left(6750 \mathrm{mosm} \cdot \mathrm{kg}^{-1}\right.$ pour le lormétazéparn, 4900 mosm $\cdot \mathrm{kg}^{-1}$ pour l'étomidate). Des signes cliniques comme une tachycardie, une hypotension artérielle ou des réactions allergiques n'ont été notés dans aucun cas. Cette libération limitée d'histamine semble consécutive au dommage tissulaire et érythrocytaire lié à l'hyperosmolarité.
\end{abstract}

During induction and maintenance of anaesthesia a variety of potent drugs are administered very often in rapid sequence. Each of the drugs used can potentially cause histamine release. In the last two decades many pharmacologists and anaesthesiologists have investigated numerous hypnotics, narcotics and muscle relaxants in this respect [1, 11, 13]. Among the benzodiazepines investigated so far, only flunitrazepam has been shown to release histamine [1].

Oral premedication with benzodiazepines, usually 1 hour before the operation, increasingly is replaced by the i.v. administration of parenteral formulations of these drugs 10-20 minutes prior to induction of anaesthesia. Intravenous premedication with benzodiazepines has proven to effectively reduce the myoclonic movements associated with the use of etomidate [2]. The aim of this trial is to investigate whether i.v. administration of the two benzodiazepines diazepam and lormetazepam, used in combination with etomidate, causes histamine release.

Presented at the meeting " New Trends in Anaphylactoid Risk in Anaesthesia». Nancy (France), 11-12 June 1992.

\section{PATIENTS AND METHODS}

After approval by the institutional ethics committee and after having obtained their informed consent, 10 healthy volunteers (age 20-30 years, weight $50-90 \mathrm{~kg}$ ) were investigated in this single-blind, crossover study. The investigators were not blinded because, due to its solubility characteristics, it is not possible to dilute diazepam to a volume of $5 \mathrm{ml}$, as needed for the administration of lormetazepam. The subjects had a four day recovery interval after the first anaesthesia with etomidate and premedication with one of the two benzodiazepines. The sequence of injection of diazepam and lormetazepam in every volunteer was randomized.

Following amounts of drugs were injected into a distal forearm vein : diazepam $10 \mathrm{mg} \cdot 70 \mathrm{~kg}^{-1}$ or lormetazepam $1 \mathrm{mg} \cdot 70 \mathrm{~kg}^{-1}, 30 \mathrm{~min}$ prior to etomidate $0.15 \mathrm{mg} \cdot \mathrm{kg}^{-1}$. The time table of trial procedure is schematically presented in figure 1 .

Blood samples were drawn through a cannula placed in an antecubital vein and plasma histamine levels were measured according to the fluorometric method described by LORENZ et al. [10]. Responders were subjects which presented at least a $40 \%$ increase in plasma histamine levels from the previous baseline value.

Heart rate was continuously monitored and blood pressure was measured in two min intervals.

Tirés à part: A. Doenicke. 


\section{RESULTS}

Diazepam solved in benzyl-alcohol did not release substantial amounts of histamine (slight mean increase from 0.35 to $0.61 \mathrm{ng} \cdot \mathrm{ml}^{-1}$ ). Plasma levels were well below $1 \mathrm{ng} \cdot \mathrm{ml}^{-1}$. Mean plasma histamine values $\pm \mathrm{SD}$ are presented in table I.

Table I. - Plasma histamine levels $\left(\mathrm{ng} \cdot \mathrm{ml}^{-1}\right)$ after administration of diazepam $10 \mathrm{mg} \cdot 70 \mathrm{~kg}^{-1}$ i.v. and lormetazepam $1 \mathrm{mg} \cdot 70 \mathrm{~kg}^{-1}$ i.v., $30 \mathrm{~min}$ before etomidate $0.15 \mathrm{mg} \cdot \mathrm{kg}^{-1}$ i.v.

\begin{tabular}{ccccccccc}
\hline \multicolumn{1}{c}{ Before } & \multicolumn{1}{c}{ After } & \multicolumn{2}{c}{ Before } & \multicolumn{2}{c}{ After } \\
\hline \multicolumn{3}{c}{ Diazepam } & \multicolumn{5}{c}{ Etomidate } \\
0.35 & $(0.16)$ & 0.61 & $(0.17)$ & 0.41 & $(0.12)$ & 0.54 & $(0.22)$ \\
\hline \multicolumn{3}{c}{ Lormetazepam } & \multicolumn{5}{c}{ Etomidate } \\
0.46 & $(0.22)$ & 0.98 & $(0.82)$ & 0.53 & $(0.33)$ & 0.94 & $(0.95)$ \\
\hline
\end{tabular}

Mean $\pm S D ; n=10$ voluntecrs ; crossover study with two different i.v premedications (diazepam and lormetazepam, respectively) 30 min before etomidate injection ; 4 day interval between study sessions.

Lormetazepam solved in propylene glycol showed a distinct histamine release in two subjects (fig. 1). According to the elimination kinetics of histamine the levels returned to baseline values within ten minutes. The subsequent injection of etomidate solved in propylene glycol (30 minutes later) caused a further liberation of histamine. Both volunteers did not show any cardiovascular reactions expected with these histamine concentrations. In both instances diazepam was given on the

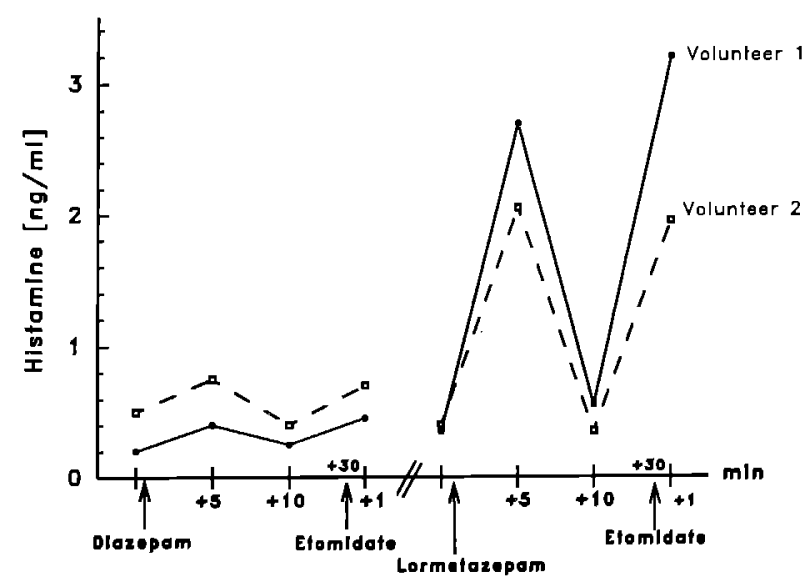

Fig. 1. - Histamine plasma levels in two volunteers after injection of diazepam, lormetazepam $\left(6,750 \operatorname{mosm} \cdot \mathrm{kg}^{-1}\right)$ and etomidate $\left(4,900 \operatorname{mosm} \cdot \mathrm{kg}^{-1}\right)$

Histamine plasma levels ( $\mathrm{ng} \cdot \mathrm{ml}^{-1}$ ) measured in blood samples drawn before and $5 \mathrm{~min}$ and $10 \mathrm{~min}$ after diazepam/lormetazepam i.v. premedication and $1 \mathrm{~min}$ after etomidate injection. Etomidate was injected 30 min after benzodiazepine administration. There was a four day interval between the two induction procedures. first trial day and lormetazepam on the second day, i.e. four days later. Histamine levels in a third volunteer rose from 0.75 to $1.15 \mathrm{ng} \cdot \mathrm{ml}^{-1}$, but did not present a true histamine release according to our definition.

Myocloni after etomidate application were not observed after premedication with lormetazepam, but was seen in a mild form in one subject after diazepam.

\section{DISCUSSION}

A previous study on 10 volunteers revealed moderate histamine release after i.v. administration of flunitrazepam in 5 subjects with a maximal histamine level of $1 \mathrm{ng} \cdot \mathrm{ml}^{-1}$. These were associated with cutaneous symptoms indicating local histamine liberation [5]. Flunitrazepam was solved in $829 \mathrm{mg} \cdot \mathrm{ml}^{-1}$ propylene glycol. In 1978 , we found elevated histamine levels associated with clinical symptoms (erythema) in volunteers receiving the muscle relaxants alloferin, pancuronium or suxamethonium in combination with etomidate [4]. At that time we would not find an explanation for histamine release after flunitrazepam or etomidate in combination with muscle relaxants.

In 1973, we had shown that etomidate did not release histamine [3]. WATKINS (personal communication) suggested the possibility of histamine release after etomidate, in such small amounts, however, that due to its fast elimination from the circulation it could not cause haemodynamic effects. This was based on the observation of subclinical reactions like chemotaxis of leukocytes through the surrounding tissue. The production of anaphylatoxins following C3-activation reached its highest value 30-40 minutes after etomidate administration, whereas methohexital showed this effect already after 5 minutes.

Our own investigations on etomidate solved in various solvents may now help to resolve the problem on histamine release after etomidate. In 1973, we had studied histamine release with a formulation of etomidate sulphate solved in phosphate buffer. This etomidate preparation had a $\mathrm{pH}$ of 3.3 and an osmolality of $270 \mathrm{mosm} \cdot \mathrm{kg}^{-1}$ [9] and did not cause histamine release [3]. Since 1977 etomidate is formulated in $35 \mathrm{vol} \%$ propylene glycol. We now know that its osmolality of $4,900 \mathrm{mosm} \cdot \mathrm{kg}^{-1}$ is conveyed by the content of propylene glycol in the drug preparation [6]. It has been shown that replacement of propylene glycol with lipid emulsion prevented thrombophlebitis of diazepam [7] and significantly reduced the occurence of pain on injection, thrombophlebitis [2] and haemolysis [12] after etomidate injection.

In the present study, the volunteers received etomidate in $35 \mathrm{vol} \%$ propylene glycol on two occasions and for premedication, once diazepam in benzylalcohol, and once lormetazepam in $50 \mathrm{vol} \%$ 
propylene glycol, respectively. Lormetazepam in propylene glycol has an osmolality of $6,750 \operatorname{mosm} \cdot \mathrm{kg}^{-1}$ [6].

We believe that not only the first injection of etomidate after diazepam but also the injection of lormetazepam and etomidate four days later, may cause osmotical tissue damage. The unphysiologic osmolality of these drugs therefore can cause histamine release from damaged endothelium and/or mast cells. The occurrence of pain and thrombophlebitis reported in previous studies $[2,14]$ can be interpreted as symptoms of irritation of the vascular tissue.

Interestingly the high histamine levels after lormetazepam ( 2.05 and $\left.2.7 \mathrm{ng} \cdot \mathrm{ml}^{-1}\right)$ and etomidate $\left(1.85\right.$ and $\left.3.2 \mathrm{ng} \cdot \mathrm{ml}^{-1}\right)$ observed in two volunteers were not associated with haemodynamic reactions or other side effects seen with similar histamine concentrations. This may be explained by the very short presence of histamine in the circulation suggested by WATKINS and the limited histamine release from destroyed blood and tissue cells, not sustained by cascade mechanism of mediators [13].

Independently from this, we advocate the replacement of solvents that convey an unphysiologic osmolality to commercial drug preparations and therefore cause vascular and cellular sequelae. Studies comparing etomidate solved in propylene glycol and etomidate solved in lipid emulsion with medium chain triglycerides have clearly demonstrated the advantages - no pain on injection, no thrombophlebitis, no haemolysis - of the preparation containing the lipid solvent at a physiologic osmolality (400 $\operatorname{mosm} \cdot \mathrm{kg}^{-1} ; \mathrm{pH}=7.6$ [6]) [2].

Since February 1992, etomidate is available in Germany in a medium chain triglycerides containing lipid emulsion (Etomidat-Lipuro (i)). A new solvent should also be found for other drugs, especially benzodiazepines like lormetazepam, lorazepam or flunitrazepam, yet solved in propylene glycol.

Promising results have been presented by HABAZETTL et al. in animal studies with propanidid formulated in liposomes. They reported a dramatic reduction of mortality due to anaphylactic reactions in rats from $86 \%$ with propanidid solved in cremophor vs $0 \%$ propanidid in the liposome formulation [8].

\section{REFERENCES}

1. Doenicke A, EnNis M, Lorenz W. Histamine release in anesthesia and surgery: a systematic approach to risk in the perioperative period (pp 41-66). In : International Anesthesiology Clinics, vol. 23 : Anaphylactoid reactions in anesthesia, DJ SAGE ed. Little, Brown \& Co, Boston, 1985.

2. Doenicke A, Kugler A, Vollmann N, Suttmann $H$, TAEGER K. Etomidat mit einem neuen Lösungsvermittler. Klinisch-experimentelle Untersuchungen zur Venenverträglichkeit und Bioverfügbarkeit. Anaesthesist, 39: 475-480, 1990.

3. Doenicke A, Lorenz W, Beigl R, Bezecny H, Uhlig G, Praetorius B, Mann G. Histamine release after i.v. application of short-acting hypnotics. A comparison of etomidate, althesin CT 134 and propanidid. Br $J$ Anaesth, 45: 1097-1104, 1973

4. Doenicke A, Lorenz W, Hug P. Histamine et étomidate. Ann Anesth Fr, 19 : 207-213, 1978.

5. Doenicke A, Lorenz W. Histaminliberierung durch Flunitrazepam (pp 62-66). In : Klinische Anaesthesiologie und Intensivtherapie, vol. 17: Rohypnol (Flunitrazepam). AhnefEld FW et al. eds. Springer, Berlin, 1978.

6. Doenicke A. Nebauer AE, Hoernecke R, Mayer $M$, RoIzen MF. Osmolalities of propylene glycol-containing drug formulations for parenteral use. Should propylene glycol be used as a solvent? Anesth Analg, 75 : 431-435, 1992.

7. Graham CW, Pagano RR, Katz RL. Thrombophlebitis after intravenous diazcpam. Can it be prevented? Anesth Analg, 56 : 409-413, 1977.

8. Habazettl $H$, Vollmar B, Röhrich $F$, Conzen $F$, Doenicke A, Baetimann A. Anästhesiologische Wirksamkeit von Propanidid als Liposomendispersion. Eine experimentelle Studie mit Ratten. Anaesthesist, 41 : 448-456, 1992.

9. Hendry JGB, Miller BM, Lees NW. Etomidate in a new solvent. A clinical evaluation. Anaesthesia, 32 : 996-999, 1977.

10. Lorenz W, Thon $K$, Neugebauer E, Stöltzing $H$, Ohmann CH. Weber D, Schmal A, Hinterlang E, Barth $H$, Kusche J. Reliability and practicability of the fluorometric-fluoroenzymatic histamine determination in pathogenetic studies on peptic ulcer : detection limits and problems with specificity. Agents Actions, 21 : 1-25, 1987.

11. Moss $\mathbf{J}$, Rosow CE. Histamine release by narcotics and muscle relaxants in humans. Anesthesiology, 59: 330-339, 1983.

12. Nebauer aE, Doenicke A, Hoernecke R, Angster R, MAYER M. Does etomidate cause haemolysis ? $B r \quad J$ Anaesth, 69 : 58-60, 1992.

13. Watkins J. Allergic and pseudoallergic mechanisms in anesthesia (pp 17-40). In : International Anesthesiology Clinics, vol. 23: Anaphylactoid reactions in anesthesia. DJ SaGe ed. Little, Brown \& Co, Boston, 1985.

14. Zacharias M, Clarke RSJ, Dundee JW, Johnston SB. Venous sequelae following etomidate, $\mathrm{Br} J$ Anaesth, 51 : $779-783,1979$

ABSTRACT: Many drugs, especially when given in rapid sequence can cause histamine relcase. Ten healthy volunteers were premedicated with diazepam $10 \mathrm{mg} \cdot 70 \mathrm{~kg}^{-1}$ i.v. and lormetazepam $1 \mathrm{mg} \cdot 70 \mathrm{~kg}^{-1}$ i.v., respectively, $30 \mathrm{~min}$ prior to etomidate $0.15 \mathrm{mg} \cdot \mathrm{kg}^{-1}$ i.v. in a single-blind, crossover study. The benzodiazepine lormetazepam and the hypnotic etomidate caused distinct increases in histamine plasma levels in two subjects. Maximal histamine levels after lormetazepam were 2.05 and $2.7 \mathrm{ng} \cdot \mathrm{ml}^{-1}$, and after etomidate 1.85 and $3.2 \mathrm{ng} \cdot \mathrm{ml}^{-1}$, respectively. Both drugs are solved in propylene glycol, a solvent that conveys very high osmolality (lormetazepam $6750 \mathrm{mosm} \cdot \mathrm{kg}^{-1}$, etomidate 4900 mosm $-\mathrm{kg}^{-1}$ ). Clinical symptoms, like tachycardia, hypotension or allergic reactions, associated with similar histamine levels were not seen in either case. This limited histamine release appears to be caused by osmotic damage of tissue and blood cells. 